\title{
Livelihoods and Rural Poverty Reduction in Kenya
}

\author{
H. Ade Freeman, F. Ellis and E. Allison*
}

This article describes research linking micro-level outcomes to macro-level strategies with respect to rural poverty reduction in Kenya. It is set against a background in which a new government, elected at the end of 2002, is wrestling with how to break away decisively from previously unfavourable norms in the conduct of public life. The research undertaken in ten villages in Suba and Bomet districts in 2001 and 2002 confirms governance problems as having a broadly debilitating effect on rural livelihoods. Rolling back this pattern of public service behaviour needs to be made a priority; otherwise national goals to improve education, health and the transport infrastructure will reap significantly lower gains than are potentially possible.

\section{Introduction}

Until early 2003, Kenya had engaged only minimally in the donor-government framework that in other countries of the region has led to endorsement of a process of Poverty Reduction Strategy Papers (PRSPs) and resulting qualification for debt relief under the Heavily Indebted Poor Countries (HIPC) Initiative. This seems to have been due in part to Kenya having a per capita income that placed it just above the ceiling income range of the priority HIPC countries, but perhaps more relevantly was associated with lapses in past policy commitments to donors. ${ }^{1}$ Kenya published a PRSP in June 2001 (Government of Kenya, 2001) but, because of the general stand-off at that time between government and donors with respect to aid flows, this remained in something of a limbo. Two strategic documents addressing similar issues to those of the PRSP were produced during the transition to the new government that took office in January 2003: the manifesto of the incoming National Rainbow Coalition government (NARC, 2002) and a Strategy for Economic Recovery (Government of Kenya, 2003). ${ }^{2}$ The stated intention of the Kenya government at the time of writing is to achieve a

\footnotetext{
Ade Freeman is at ICRISAT, PO Box 39063, Nairobi, Kenya, and Frank Ellis (F.Ellis@uea.ac.uk) and E. Allison are at the School of Development Studies, University of East Anglia, Norwich, NR4 7TJ, UK. This article is part of a series of country studies arising from a research programme entitled LADDER, standing for Livelihoods and Diversification Directions Explored by Research, an acronym devised to evoke the notion of 'climbing out of poverty' (see Ellis and Bahiigwa, 2003; Ellis and Mdoe, 2003; Ellis et al., 2003; Ellis and Freeman, 2004). The programme was funded by the Policy Research Programme of the UK Department for International Development (DFID); however, the findings and views expressed here are solely the responsibility of the authors and are not attributable to DFID.

1. The World Bank's last Country Assistance Strategy (CAS) for Kenya advises 'a very limited lending strategy' and states that 'Kenya is currently in the low case scenario' (World Bank, 2000).

2. Both these documents place strong emphasis on growth and employment generation as an approach to poverty reduction in Kenya.

(c) Overseas Development Institute, 2004.
}

Published by Blackwell Publishing, Oxford OX4 2DQ, UK and 350 Main Street, Malden, MA 02148, USA. 
convergence between these documents in order to avoid multiple policy processes with differing origins and emphases.

The Kenya PRSP specifies twin goals of economic growth and poverty reduction, and then breaks these down into a set of subsidiary objectives, mainly to do with moving public expenditure management into line with poverty reduction priorities, and a set of principles stated as giving a voice to the poor, participation, transparency and equity of access. These principles set the stage for themes that are restated throughout the document, although, in common with many other PRSPs, only tenuous links are achieved between the catch phrases that imbue the themes and principles and the sectoral and sub-sectoral plans and targets, which could have originated in almost any position document of the past thirty years. The most interesting insights of the PRSP arise from factors identified during the consultation exercise. These attribute rising poverty especially to poor marketing services; deteriorating livestock services; insecurity, including banditry, hijacking, raiding stock, looting, rape and murder; low wages; bad governance; land issues, especially with respect to unequal gender rights; and the cost and low quality of health and education services.

As with most PRSPs, the challenge lies in making the connection between insights into the circumstances of being poor in Kenya and the priorities established in sectoral plans, which are mainly to do with deliverable targets related to large-scale expenditures such as education, health and rural roads. While meeting education, health and rural roads targets is a laudable enough objective, these achievements will have lower than expected impacts on poverty reduction in the long term if ordinary poor individuals are unable to exercise their capabilities because of the kinds of institutional blockages and disabling public sector environments that are hinted at by the outcomes of the consultative process.

This article seeks to go beyond the readily identifiable broad-scale measures that tend to dominate poverty reduction discussions within the purview of PRSPs, and to provide a more multi-faceted understanding of the factors that distinguish the rural poor from the rural better-off, the micro- and local-level economic, social and political constraints they confront, and the cross-sectoral patterns of activity they pursue in constructing viable livelihoods. ${ }^{3}$ These local-level understandings are then utilised to reflect on the adequacy or otherwise of the dominant lines of thinking that appear in the existing PRSP, and in associated sectoral policies set out within it. The research underlying the article was guided by the sustainable livelihoods framework, with its emphasis on taking an integrated view of people's livelihoods and the factors that hinder or help them to construct routes out of poverty (Carney, 1998; Scoones, 1998; Ellis, 2000).

The article proceeds as follows. Section 2 summarises features of past political and economic patterns and trends in Kenya that serve as a backdrop to the discussion of rural poverty reduction. This is followed by a brief description of the research methods, and a summary of household- and village-level livelihood characteristics that emerge from qualitative and quantitative research. The latter exercise focuses on the asset status of rural citizens, the income-generating activities in which they engage, and the

3. The diversity of rural livelihoods in low-income countries means that previous assumptions about the preeminent role of agriculture in poverty reduction needs to be revised. See, for example, Bryceson (1996); Bryceson and Jamal (1997); Ellis (1998; 2000). 
institutional environment within which livelihood strategies are adopted and adapted. Finally, the micro-level findings in these areas are linked back to the macro level of poverty reduction decision-making in Kenya with a view to identifying factors that may tend to be overlooked, and that need to be properly considered and debated if real progress in rural poverty reduction is to be achieved.

\section{Kenya background}

Kenya is now in a position where political change offers prospects for new directions in the conduct of public life and in the government policies and practices that could potentially ensue. In elections held in late December 2002, a coalition of opposition parties described as the National Rainbow Coalition (NARC) decisively defeated the Kenya African National Union (KANU) that had held power without a break since independence in $1963 .{ }^{4}$ Notwithstanding that many senior NARC politicians had at one time or another held posts in successive governments of the outgoing president, Daniel Arap Moi, many people in public life in Kenya as well as external observers regard the new government as symbolising a genuine departure from the way power and public office have tended to be exercised during the preceding two or three decades.

It is too early to gauge the effects of the foregoing on economic performance or on trends in rural or urban poverty. The new government has acted quickly on some fronts, notably introducing free universal primary education within a few days of taking office. However, whether real improvements will occur in the quality and standard of living of the majority of people will take several years to emerge. What is certain is that Kenya has a somewhat dire past record with respect to a broad range of economic, social, political and governance indicators, so much so that the incidence of poverty is estimated to have risen sharply in the 1990s, and disillusioned donors had reduced official development assistance by 2000 to the point that it was half the per capita level of neighbouring Uganda and Tanzania. ${ }^{5}$

Kenya had a total population estimated at 30.7 million in 2001, growing at $2.4 \%$ per year, and a per capita gross national income of US\$340, lower in 2001 than in 1987. ${ }^{6}$ Taking the longer-term view, economic growth fell from an annual $7 \%$ in the 1960 s to $5 \%$ in the 1970 s, $4 \%$ in the 1980 s, and $2.4 \%$ in the 1990 s. Kenya is a much more industrialised country than its neighbours, with only $20 \%$ of GDP originating in agriculture, as compared to over $40 \%$ in Uganda and Tanzania. On the other hand, $67 \%$ of Kenya's population live in rural areas, the same proportion as in Uganda, so it is to be expected, and is indeed the case, that there is a high incidence of rural poverty,

4. Until January 2003, Kenya had had only two heads of state in its post-independence history: Jomo Kenyatta from 1963 until his death in 1978 (15 years), and Daniel Arap Moi from 1978 to 2002 (25 years). During most of this period Kenya was de facto or de jure a one-party state, and ten years after the introduction of multi-party democracy in 1992, KANU absorbed the then main opposition party (National Development Party) in 2002.

5. In 2000 , aid per capita to Kenya was US\$17.0 as compared with US\$36.9 in Uganda and US\$31.0 in Tanzania (World Bank, 2002).

6. The data cited are from the Kenya Data Profile available on the World Bank website (www.worldbank.org/afr/ke). 
estimated as rising from 46 to $53 \%$ of the rural population between 1992 and $1997 .{ }^{7}$

The economic growth figures cited above show that, immediately postindependence, the Kenya economy performed rather well. In the 1960s and 1970s, the small-farm sector did particularly well, although its rapid growth was mainly associated with cash-crop production in the context of reasonably buoyant world markets, and food-crop farming did not fare so well (Francis, 2000). ${ }^{8}$ Crop marketing boards, either carried over from the colonial period or created post-independence, initially seemed to have been effective, and were even held up as exemplary success stories (Lamb and Muller, 1982; Jabara, 1985). Enviable contrasts were made with Tanzania to show that private sector agricultural development in Kenya was superior to the socialist path followed in Tanzania (Johnston, 1989; Lofchie, 1989).

Of course, not everyone concurred in these up-beat assessments even then, and Kenya, like other post-independence African countries, received its fair share of political economy analysis that emphasised rural differentiation, class formation, and the ambiguous role of the post-colonial state (for example, Leys, 1975; Kitching, 1980). In hindsight, some of this critical literature anticipated rather accurately the lack of separation between public office and private accumulation that was later to blight Kenya's development prospects. Early contrasts with Tanzania in terms of supposedly less crowding-out of private rural markets by parastatal bodies turned out to be largely illusory, with Kenya proving as reluctant as any other country to dismantle poorly functioning public marketing agencies. The size and spread of the government sector in Kenya continue to be important contributors to poor economic performance. In December 2001, the public sector accounted for $40 \%$ of total wage employment, a substantial proportion of which represented jobs without the resources to undertake any meaningful activities. This has remained up to the early 2000 s one of the critical points of dispute between donors and government over the conduct of public policy (World Bank, 2000).

Patterns of post-independence urban enterprise in Kenya gave rise to the concept of the informal sector as a collection of non-farm private enterprises that operated outside the measured 'formal' economy, but were thought to contribute disproportionately to the employment and incomes of the poor because of the labour intensity of their production methods (ILO, 1972). ${ }^{9}$ Subsequently there was a debate both in Kenya itself and in the wider literature as to whether the informal sector could act as a vehicle for dynamic growth or was merely a low-level absorber of unskilled labour (for example, Livingstone, 1991; Saith, 1992). ${ }^{10}$ Since the 1980s, this type of enterprise has been referred to in Kenya as the jua kali (lit. 'hot sun') sector, and it is

7. The rural poverty estimates cited are contained in the 2001 PRSP (GoK, 2001). It may not be possible to make a strict comparison of poverty estimates derived from different rounds of the Welfare Monitoring Surveys in Kenya, all of them different with respect to the timing of survey administration, the content of the questionnaires, and the quality of data gathered.

8. Francis (2000: Ch.1) also provides a useful account of land resettlement in post-independence Kenya. In addition, see relevant chapters in Heyer et al. (1976) and Killick (1981).

9. King (1996: 7) attributes the origin of the term 'informal sector' to a conference paper presented by Keith Hart at Sussex University in September 1971, entitled 'Informal Income Opportunities and the Structure of Urban Employment in Ghana'. Nevertheless, its widespread use in development studies took off from the ILO Kenya report.

10. Livingstone characterises the informal sector as a 'sponge' economy, meaning that it has a surprisingly adaptable capacity to absorb labour, but does so at bare minimum levels of productivity and earnings. 
estimated to account for about $12 \%$ of GDP (King, 1996). Studies have revealed great variation within the sector with respect to the survival rate of firms and the levels of income they generate (Daniels and Mead, 1998; Daniels, 1999). King (1996) concludes that occasional government forays into policy-making for the jua kali sector have made scant difference to its size, diversity, growth or income-generating characteristics.

Many different propositions about rural growth, migration, gender and the environment have originated from or been tested using Kenya case-study material. Francis (2000) provides a perceptive guide to much of the literature in her chapter sections on Kenya. The flows and ebbs of the remittance economy have been a crucial feature throughout, leading to differing effects on the economic viability and social relations of rural livelihoods in different places and time periods. When urban labour markets were expanding and wages were rising, remittances provided resources that could be used to intensify agriculture and raise farm productivity (Evans and Ngau, 1991; Tiffen et al., 1994). However, this may have contributed to increasing inequality in rural areas (for example, Murton, 1999). Remittance income could also be used to fund education, so that the next generation would have access to better paid non-farm work (Francis and Hoddinott, 1993; Hoddinott, 1994). Economic stagnation and decline in the 1990s meant a shrinking of the remittance economy and more stress placed on social relations in the household, as families have had to adapt to returning migrants, diminishing budgets, and poor market opportunities in rural areas (Francis, 1998; 2000).

Both rural and urban Kenya have suffered from a deteriorating climate of public service delivery over the past two decades. In urban areas, this is manifested by disintegrating infrastructure and interruptions in electricity and water supplies. In rural areas, it is manifested by poor maintenance of rural feeder roads, high cost and poor delivery of education and health services, uneven provision of agricultural advice, and poor market outreach for farm inputs and outputs. There is also the phenomenon that may be characterised as 'multiple shaking down', whereby ordinary rural Kenyans are prone to being required by those with some sort of authority over them to pay a variety of spurious fees and fines. ${ }^{11}$ Some of these trends may be laid at the door of cuts and charges arising from structural adjustment programmes. Others are symptomatic of the more general governance problem for which Kenya unhappily has become something of a by-word in its recent history.

The findings of rural livelihoods research that follow must be interpreted in the light of these general considerations. Poor governance always favours the better-off over the poor, since the better-off are more able to navigate round the blockages and disabling contexts that everyone has to deal with while trying to go about making a living. The potential for success in rural poverty reduction in Kenya will greatly depend on the ability of the new government to roll back disabling and discouraging public sector institutional environments. The following sections seek to capture patterns of rural livelihoods, and to identify the local-level constraints and blockages that need to be considered in future macro-level decisions about the shape and direction of poverty reduction efforts.

11. The phrase 'multiple shaking down' was suggested to one of the authors by a senior member of the new Kenya government, at the time of a conference on rural livelihoods and poverty reduction organised by ICRISAT, Nairobi, in January 2003. 


\section{Research approach and methods}

The field research methods underlying this article were developed in consultation with research partners across four different countries, and originated in the approach to rural poverty reduction known as the sustainable livelihoods framework (Scoones, 1998; Bebbington, 1999). This framework lays emphasis on achieving an 'all-round' understanding of making a living, comprising not just the conventional categories of employment and incomes, but the asset basis of people's livelihoods, the vulnerability factors they confront, and the public sector institutional environment that either hampers or facilitates the construction of improving livelihood circumstances over time. As articulated by Moser (1998: 1), the livelihoods approach seeks 'to identify what the poor have rather than what they do not have' and '[to] strengthen people's own inventive solutions, rather than substitute for, block or undermine them'.

The basic categories of the livelihoods framework are described in several different diagrammatic versions, although these tend to contain similar components and implied relationships between them (Scoones, 1998; Carney, 1998; Ellis, 2000: 30). A simplified version is represented at Figure 1 below. This has five components that are widely regarded as the building blocks of livelihoods work. At the centre is an economic relationship between livelihood assets, the activities in which individuals or families engage using their assets, and the outcomes that result from these activities in terms of improving or worsening the welfare and wellbeing of the individual or family. This economic relationship is, however, embedded in social and political relations as implied by the policy and institutional context. It is also more or less prone to deterioration according to risk factors that make up the vulnerability context of people's livelihoods. Figure 1 is deliberately devoid of arrows implying causality. Livelihoods are complex and changing. Although they, of course, encompass links between cause and effect, as well as cumulative processes, these cannot be adequately captured in such a simplified representation.

Figure 1: Livelihoods Framework

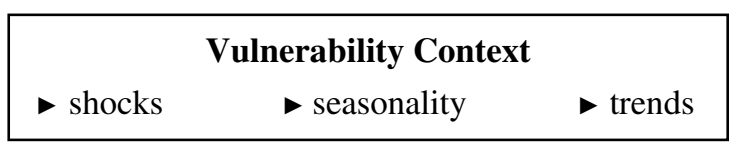

\begin{tabular}{|l|l|}
\hline Assets & Octivities \\
\hline
\end{tabular}

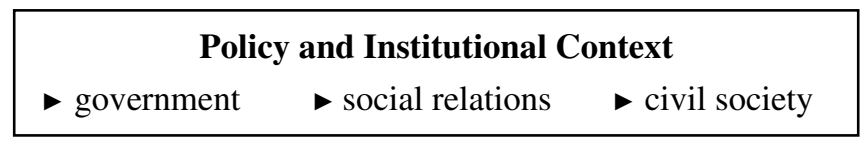

The data demands of a livelihoods investigation are potentially awesome. However, a judicious mix of qualitative and quantitative methods can help to reduce 
these to a manageable level (Kanbur, 2001; White, 2002). In particular, qualitative methods are often more insightful for capturing the social and institutional context of people's lives than quantitative methods (Booth et al., 1998). In view of these considerations, the fieldwork research underlying this article adopted a division of tasks in which a qualitative component addressed the institutional context of livelihoods and changing livelihood circumstances at community level, while a quantitative component addressed assets, activities, incomes and vulnerability factors at household level.

Research was undertaken in Suba and Bomet districts in Kenya, two districts that contain above-average poverty counts with respect to the national poverty profile. ${ }^{12}$ The study locations were chosen in order to capture livelihood 'gradients' of varying kinds, as well as to investigate particular poverty policy issues related to fishing communities on Lake Victoria. ${ }^{13}$ The key livelihood gradients that determined village selection were intensive versus extensive farming, small versus large farm size, variations in rainfall and other agro-ecological conditions, variations in the extent of livestock keeping, proximity to or remoteness from public infrastructure and services, and variations in access to non-farm activities. Five villages were purposively selected in each district, and within each village a stratified random sample of 35 households was taken, by first categorising village populations into three wealth groups utilising participatory wealth ranking procedures (Grandin, 1988). ${ }^{14}$

The purpose of wealth ranking, aside from insights into relative poverty and wealth gained from the exercise itself, was to ensure that household samples represented the full range of livelihood circumstances to be found in villages, rather than being accidentally clustered around the mode of the range. The procedure described was not designed to make inferences about larger populations. Purposive selection from districts to villages and to households set out to capture prevalent experiences of making a living in rural Kenya. Statistical analysis conducted on the resulting dataset refers only to sample characteristics, and gains its interest from within-sample comparisons of livelihood indicators across different asset or income groups, not from a claim to represent national patterns.

The location of study districts and villages is shown in Figure 2 below. Suba district is in Nyanza Province, and key features are its remoteness, its relatively recent pattern of settlement, ${ }^{15}$ its coastline on Lake Victoria, and its offshore islands that include Rusinga Island connected to the mainland by a causeway and Mfangano Island. Bomet district is in Rift Valley Province, and its chief feature is a steep agro-ecological gradient going from an upper elevation high rainfall tea-growing zone in the north to a lower elevation semi-arid zone in the south. Altitude varies roughly from $2500 \mathrm{~m}$ in the north to $1800 \mathrm{~m}$ in the south. Conditions in the north permit intensive cultivation of

12. Suba district (as part of the previous larger Homa Bay district) was classified in the 1997 Welfare Monitoring Survey (WMS III) as the poorest district in Kenya, with $77 \%$ of the population below the absolute poverty line. Bomet had $63 \%$ of its population below the poverty line.

13. Lake fisheries represent the fourth largest export sub-sector in Kenya, and are thought to provide either direct or indirect employment for half a million people.

14. With a list of households in each wealth group, 10 households were randomly chosen from each of the well-off and middle categories, and 15 households from the poor category; thus the sample has a slight bias towards the lower end of the wealth range, although this effect is negligible compared with variations between villages in the proportions assigned to different wealth categories.

15. Much of Suba district was settled in the first decade after independence, with some areas comprising designated resettlement schemes. 
perennial cash crops or sequential seasonal crops, while in the south a single reliable rainy season permits just one annual crop of maize, millet or sorghum. In both districts, livestock are an important component of livelihoods in all villages, although more so in Bomet than in Suba, and less so in fishing villages than other villages within Suba.

\section{Figure 2: Maps of Suba and Bomet Districts, Kenya (showing location of study villages)}

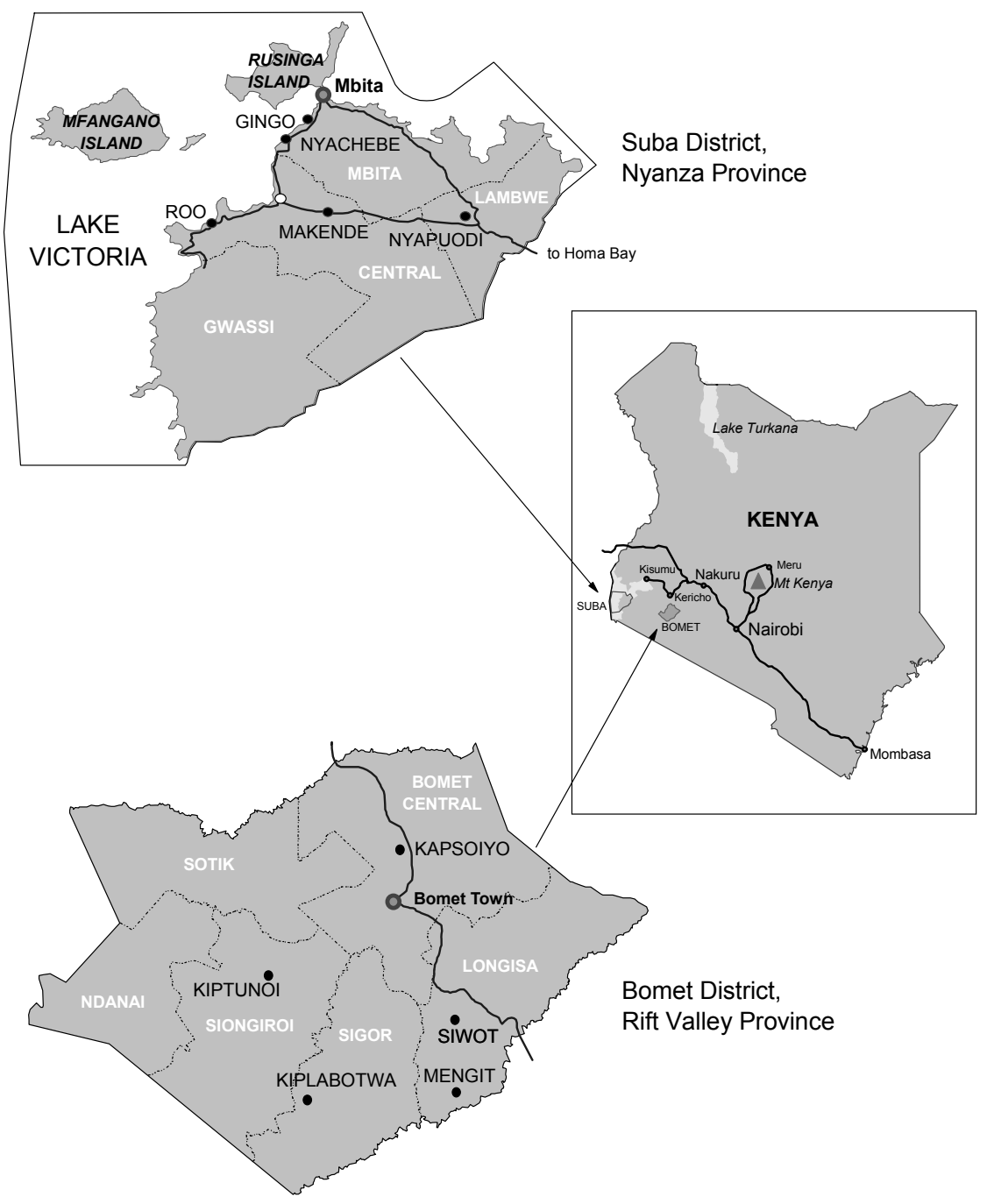

A list of the study villages and their key natural resource features is provided in Table 1 . When this is taken in conjunction with the maps, certain attributes of village selection for livelihoods fieldwork become apparent. In Suba district an important subsidiary line of enquiry concerned the livelihoods of families specialising in artisanal 
fishing or combining fishing with farming. This was partly to investigate the widely held but seldom tested proposition that artisanal fishing folk are 'the poorest of the poor' (Pauly, 1997). The five villages selected in Suba district represent a spatially scattered collection of differing agro-ecological situations, combined with the ability in three of them to examine poverty and policy issues related to fishing as a source of livelihood. In Bomet district, the five villages describe a transect across the district aiming to capture the agro-ecological gradient described in the preceding paragraph.

\section{Table 1: Study villages in Suba and Bomet Districts, Kenya}

\begin{tabular}{lccc}
\hline Location & Division & Village & NR Features \\
\hline Suba Inland & Lambwe & Nyapuodi & maize, sorghum, beans \\
& Central & Makende & maize, sorghum, beans \\
Suba Lake & Central & Roo & fishing and farming \\
& Central & Gingo & fishing and farming \\
& Mbita & Nyachebe & fishing and farming \\
Bomet & Bomet Central & Kapsoya & tea and pyrethrum \\
& Songiroi & Kiptunoi & maize and livestock \\
& Sigor & Kiplabotwa & semi-arid maize \\
& Longisa & Mengit & semi-arid maize/millet \\
& Longisa & Siwot & hillside mixed crops \\
\hline
\end{tabular}

For the purposes of the summary analysis of household level data that follows, villages are collected into three groups: the three Suba lakeside villages are grouped as Suba Lake; the two interior villages in Suba are grouped as Suba Inland; and all five Bomet villages are taken together. However, observations will be made where relevant concerning variations between villages that are significant for interpreting rural livelihoods for poverty reduction purposes.

\section{Assets and rural livelihoods in Kenya}

Reflecting its origins in a food security literature, in particular the endowments and entitlements approach of Amartya Sen (Sen, 1981), the sustainable livelihoods approach places a lot of emphasis on ownership of, or access to, assets that can be put to productive use as the building blocks by which the poor can construct their own routes out of poverty. Assets in this regard comprise land, livestock, human capital (education level and health status), farm implements, savings or access to credit, infrastructure (e.g. road or electricity access) and, possibly, social capital (quality of associative activity and familial networks). ${ }^{16}$ What seems to differentiate the better-off from the poor in rural society is the ability to trade-up assets in sequence - for example, cash from non-

\footnotetext{
16. Most versions of the sustainable livelihoods framework contain social capital as one of five principal categories of assets (the other four being natural, human, physical and financial capital). Social capital enjoyed a short-lived authenticity as a development studies construct in the late 1990s; however, it has been shown to be ambiguous and flawed, and is invoked less readily now.
} 
farm income to farm inputs to higher farm income to land or to livestock. Conversely, asset disposals caused, for example, by the medical costs of prolonged ill health, can result in a spiral down into poverty.

Wealth-ranking exercises conducted in the ten study villages revealed patterns in common across villages and districts in the attributes considered by villagers themselves to define relative wealth and poverty. Households considered 'well-off' are typically defined by owning more than 4 ha of land, 10 or more cattle, 10 or more goats, sheep or pigs, 1 or 2 ox ploughs, and a house with brick walls and a corrugated iron roof. Further, they are food-secure all year round, hire labour seasonally, are educated up to primary level or above, and engage in diverse non-farm activities (trading, milling, shop-keeping, brick-making, lodgings, bars) in addition to farming. In fishing villages, the better-off possess 2-3 fully equipped boats, employ 4-6 fishing labour, engage in fish trading, and own plots on which shacks are built to accommodate hired labour.

A middle category of households are defined by owning less or a poorer quality of all these assets. For example, livestock holdings would tend to average around 5 cattle and 5 goats, and, amongst fishing families, ownership of one boat with associated gears would be the norm. Towards the lower end of this category, households tend to be net sellers rather than buyers of labour, they are net buyers of food and sometimes seasonally food-insecure, and they engage in low-return non-farm activities such as the collection of firewood, although some family members may have low-paid government jobs. Households regarded as poor tend to own less than 0.5 ha land or no land at all, own few if any cattle or goats, have houses in poor repair with thatched roofs, are foodinsecure for much of the year, and depend on selling labour or on safety-net supports for survival. Social groups typically assigned to the poor category in wealth-ranking exercises are the elderly whose families live away from the village, divorced or widowed women, those with chronic health problems, the disabled, and those not possessing land.

These features of asset status between different rural groups in Suba and Bomet districts are explored further, utilising results from the sample surveys undertaken in ten villages in 2001 and 2002. The distribution of assets across rural households is described in two main ways: by reference to asset-holding across income terciles or quartiles, and by reference to interval or count distributions of assets.

Taking land as an asset first, Table 2 shows how mean land ownership changes across different household income levels. The general pattern, as expected, is for a steady rise in mean land owned across the income quartiles, i.e. more land is associated with greater income; however, there are exceptions to this rule, notably the smaller farm size of the top income quartile in Suba fishing villages compared with the other income quartiles there. This is explained by the contribution of fishing to higher incomes in Suba district, such that households specialised more in artisanal fishing than in farming are situated towards the upper end of the income distribution. This feature is examined further in due course, but is an early indicator of a finding prevalent in all case-study countries, including Kenya, that artisanal fishing families are not the poorest of the rural poor; on the contrary they tend to be better-off than their purely farming counterparts in rural areas. 


\section{Table 2: Mean land ownership by income quartile, by location}

\begin{tabular}{|c|c|c|c|c|c|}
\hline \multirow[t]{2}{*}{ Sample } & \multicolumn{4}{|c|}{ Income quartile } & \multirow[t]{2}{*}{ Total $(n=1120)$} \\
\hline & $\mathbf{I}$ & II & III & IV & \\
\hline \multicolumn{6}{|l|}{ Land owned (ha) } \\
\hline Suba Inland $(\mathrm{n}=70)$ & 2.17 & 1.59 & 2.93 & 3.06 & 2.43 \\
\hline Suba Lake $(\mathrm{n}=105)$ & 1.78 & 1.89 & 2.48 & 1.98 & 2.04 \\
\hline Bomet $(n=175)$ & 1.13 & 1.31 & 1.71 & 1.87 & 1.50 \\
\hline All villages & 1.41 & 1.79 & 2.02 & 2.17 & 1.85 \\
\hline
\end{tabular}

Source: Sample survey conducted in June-August 2001 (Suba) and October-November 2002 (Bomet).

The distribution of land across sample households is explored further here by reference to interval counts of land ownership (Table 3). Very few households in these sample rural areas described themselves as landless (just 3 households in non-fishing villages in Suba). However, two-thirds of all households owned less than 2 ha of land, with this proportion varying according to the intensity of competition for land between locations, being highest for the Bomet villages that also had the lowest proportion of farm sizes above $5 \mathrm{ha}$, at just 3\%. Within Bomet, there are notable differences in mean farm sizes and farm size distributions, corresponding to the agro-ecological gradient that was sampled. Farm sizes are smaller, and more households have holdings under 2 ha, in high potential areas compared to low potential areas. ${ }^{17}$

\section{Table 3: Land ownership distribution across sample households (\%)}

\begin{tabular}{lcccc}
\hline Ownership range & Suba Inland & \multicolumn{2}{c}{ Study locations } \\
& $(\mathbf{n = 7 0})$ & $\begin{array}{c}\text { Suba Lake } \\
(\mathbf{n = 1 0 5})\end{array}$ & $\begin{array}{c}\text { Bomet } \\
(\mathbf{n = 1 7 5})\end{array}$ & $\begin{array}{c}\text { Total } \\
(\mathbf{n = 3 5 0})\end{array}$ \\
\hline Less than 0.5 ha & 10.0 & 18.1 & 24.0 & 29.4 \\
Less than 1 ha & 28.6 & 28.6 & 50.3 & 39.4 \\
Less than 2 ha & 58.6 & 63.8 & 73.7 & 67.7 \\
Between 2 and 5 ha & 28.5 & 31.4 & 23.4 & 26.9 \\
More than 5 ha & 12.9 & 4.8 & 2.9 & 5.4 \\
\hline
\end{tabular}

Source: Ibid.

Similar findings occur with respect to livestock holding across different income levels, as shown in Tables 4 and 5. For this purpose, all livestock possessed by households were aggregated into a single measure of cattle equivalent units (CEUs). Again, the general case is for livestock ownership to increase steadily across the income quartiles, although there are exceptions to this rule and again the influence of fishing income is seen in the lower importance of livestock for achieving the highest household incomes in Suba fishing villages. Bomet sample villages exhibited generally lower

17. The range is between a mean farm size of just over 1 ha in Siwot and Kapsoiyo villages and 2 ha in Mengit village. 
mean livestock holdings than those seen in Suba district, and the lowest income quartile in Bomet possessed notably fewer livestock than the other income groups there. Another way of looking at unequal livestock holdings is by reference to non-ownership, and it can be seen in Table 5 for the sample as a whole that more than a quarter of households did not own cattle, more than half did not own goats or sheep, and $20 \%$ did not own chickens.

\section{Table 4: Mean livestock ownership by income quartile, by location}

\begin{tabular}{lccccc}
\hline Sample & \multicolumn{4}{c}{ Income quartile } & Total $(\mathbf{n}=1120)$ \\
& I & II & III & IV & \\
\hline Livestock CEUs ${ }^{a}$ & & & & & \\
Suba Inland (n=70) & 4.68 & 3.53 & 9.78 & 7.70 & 6.43 \\
Suba Lake (n=105) & 2.87 & 4.49 & 6.99 & 4.82 & 4.81 \\
Bomet (n=175) & 1.60 & 4.18 & 4.11 & 4.84 & 3.68 \\
All villages & 2.85 & 4.31 & 5.16 & 5.95 & 4.57 \\
\hline
\end{tabular}

Note: (a) Cattle equivalent units (CEUs) are based on mean price ratios between different livestock types, and are cattle $=1$, donkeys $=0.26$, goats $=0.12$, sheep $=0.1$, pigs $=0.07$, turkeys $=0.03$ and chickens $=$ 0.02 .

Source: Ibid.

\section{Table 5: Proportions of sample households lacking livestock assets (\%)}

\begin{tabular}{|c|c|c|c|c|}
\hline \multirow[t]{2}{*}{ Area owned } & \multicolumn{4}{|c|}{ Study area } \\
\hline & $\begin{array}{c}\text { Suba Inland } \\
\quad(n=70)\end{array}$ & $\begin{array}{l}\text { Suba Lake } \\
(\mathrm{n}=105)\end{array}$ & $\begin{array}{c}\text { Bomet } \\
(n=175)\end{array}$ & $\begin{array}{c}\text { Total } \\
(\mathbf{n}=\mathbf{3 5 0})\end{array}$ \\
\hline No cattle & 24.3 & 40.0 & 22.9 & 28.3 \\
\hline No goats & 54.3 & 42.9 & 57.7 & 52.6 \\
\hline No chickens & 15.7 & 17.1 & 22.9 & 19.7 \\
\hline
\end{tabular}

Source: Ibid.

In addition to land and livestock, the key assets of rural families in the case-study locations are their own labour (economically active adults in the household), their educational attainment (measured here by years of education accomplished), and their ownership of productive implements and tools (measured as the aggregate value owned). Figure 3 displays the comparative level of holdings of these five assets, or asset categories, for the whole sample, divided into per capita income terciles, in the form of a radial graph. The interesting features are, first, that the top and middle income thirds of households do not differ hugely in their average possession of the five key assets (with the single exception of tools) ${ }^{18}$ and, second, that the lowest income third of

18. The result for tools is attributable to higher-wealth households possessing plough teams that enable them to plough early in the season and therefore realise higher yields. 
households is shown to be relatively lacking in all assets except the number of working adults in the household.

\section{Figure 3: Selected asset levels by income tercile, whole sample}

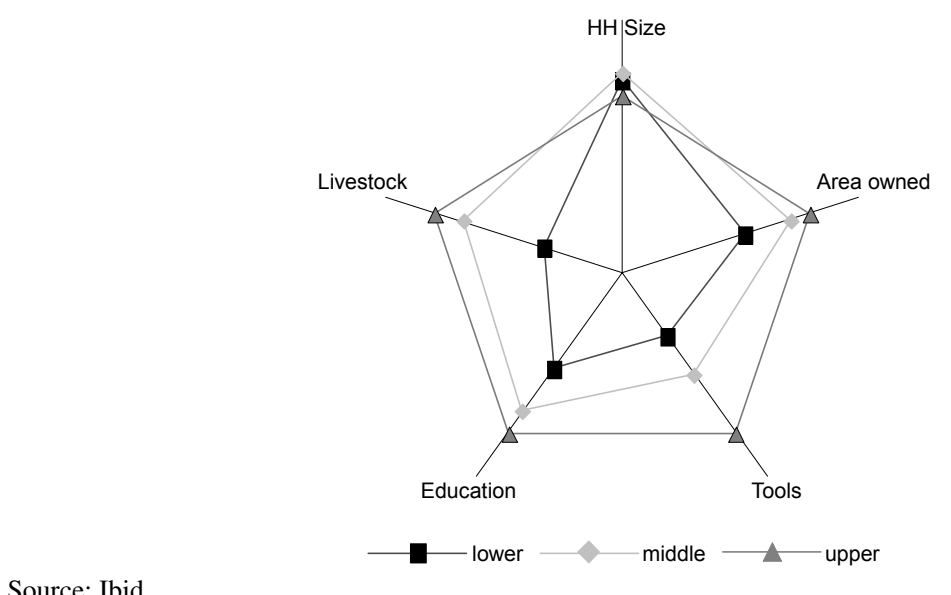

Interestingly, this basic pattern recurs across adjacent countries, with minor variations between them (Ellis and Freeman, 2004). The lower one-third of the income distribution is invariably poor in both livestock and land compared with all other households, but the position with respect to other assets is less clear-cut. In most cases, livestock ownership most evidently distinguishes the top third from the middle third of the income distribution, but in the Kenya sample this is not the case, due, as noted above, to the influence of Suba fishing households on asset-income relationships. In lakeside villages throughout the region the ownership level of fishing assets (boats and gears) was found to be an additional factor distinguishing the top income one-third of households (Allison and Mvula, 2002; Ellis and Bahiigwa, 2003).

The multiple roles of livestock in contributing to successful livelihood strategies are illustrated by the Kenya case-studies. High livestock ownership not only denotes high wealth associated with livestock as a store of value, but also implies high income, always placing bigger livestock owners in the upper per capita income ranges. Notably, however, it is not livestock itself that is the major contributor to these higher incomes. As is shown later in this analysis, the income composition of the top income quartile is dominated by non-farm self-employment income. This provides an example of the interlocking nature of relative livelihood success in rural areas. Livestock is a substitutable asset that can be sold in order to invest in land or small businesses, and, vice versa, non-farm income can be used to build up herds; the ordering of these sequences depends on the personal and market opportunities that prevail in different time periods. 


\section{Rural activities and incomes}

This section summarises findings concerning livelihood activity patterns and income levels as discovered in the case-study villages. This is done drawing on qualitative, village-level, data as well as quantitative household-level data. Some qualitative features have already been mentioned while discussing wealth-ranking categories, namely, the prevalence of non-farm business activities in describing the livelihoods of the well-off, and the reliance of the poor on hiring out their labour to the rich or, in Suba fishing villages, to fishing boat owners. The picture is refined by reference to sample survey data.

Starting with farming and livestock activities, Table 6 shows agricultural land use by sample households across the three sample locations, and for the sample as a whole. Maize dominates crop agriculture across all villages; in total nearly $40 \%$ of the sample farm area in the ten villages was sown to maize in either pure or mixed stands. In addition, sorghum is a key food grain in Suba district, corresponding to roughly $12 \%$ of the sown area across all Suba villages. Bomet land use displays a different pattern from Suba, primarily in the significance of grazing or livestock fodder areas, corresponding to $60 \%$ of sample farm area in the district. In terms of the land-use gradient within Bomet, this proportion ranges between $50 \%$ for the high altitude, high rainfall, Kapsoiyo village, and $70 \%$ for one of the semi-arid villages, Kiplabotwa, further down the escarpment. ${ }^{19}$

\section{Table 6: Land use by sample households, by study location}

\begin{tabular}{lrrrrrrrr}
\hline Land use & \multicolumn{2}{c}{$\begin{array}{c}\text { Suba Inland } \\
\text { n=70 }\end{array}$} & \multicolumn{2}{c}{$\begin{array}{c}\text { Suba Lake } \\
\text { n=105 }\end{array}$} & \multicolumn{2}{c}{$\begin{array}{c}\text { Bomet } \\
\text { n=175 }\end{array}$} & \multicolumn{3}{c}{ Total } \\
n=350 \\
ha & \multicolumn{1}{c}{$\%$} & \multicolumn{1}{c}{ ha } & \% & \multicolumn{1}{c}{ ha } & \multicolumn{1}{c}{$\%$} & \multicolumn{1}{c}{ ha } & \multicolumn{1}{c}{$\%$} \\
\hline Maize/mixtures & 90.7 & 50.9 & 91.6 & 41.8 & 72.8 & 26.5 & 255.1 & 38.0 \\
Sorghum & 27.5 & 15.5 & 18.0 & 8.2 & 0.2 & 0.1 & 45.7 & 6.8 \\
Millet & 2.2 & 1.3 & 17.5 & 8.0 & - & - & 19.7 & 2.9 \\
Other crop mixes & 16.9 & 9.5 & 4.1 & 1.9 & 24.7 & 9.0 & 45.7 & 6.8 \\
Non-food crops & 3.2 & 1.8 & - & - & 6.5 & 2.4 & 9.7 & 1.4 \\
Livestock uses & 3.2 & 1.8 & - & - & 165.7 & 60.3 & 168.9 & 25.1 \\
Rented out & 0.4 & 0.2 & 6.7 & 3.0 & 1.3 & 0.5 & 8.4 & 1.3 \\
Unspecified & 33.9 & 19.0 & 81.1 & 37.0 & 3.4 & 1.2 & 118.4 & 17.6 \\
Totals & 178.1 & 100.0 & 219.0 & 100.0 & 274.5 & 100.0 & 671.6 & 100.0 \\
\hline
\end{tabular}

Note: Table describes aggregate land-use data summed across sample households.

Source: Ibid.

The overall monetisation of the rural economy is a feature pertinent to poverty reduction efforts. If markets are working well, and trade and exchange are flourishing, then this increases the cash in circulation in rural areas and gives individuals broader

19. The proportions of land stated as under grazing in the Bomet sample villages are likely to have been overestimated for seasonal reasons, since the field research was undertaken in the non-cropping season. 
opportunities to construct pathways out of poverty. Table 7 provides sample data by study location on the output share of principal crops and livestock consumed by the household rather than sold in the market. The reliance on subsistence consumption, even in an economy as strongly non-agricultural and monetised as Kenya, is quite striking. The mean subsistence share for maize across all locations is $90 \%$, with this reaching nearly $100 \%$ in Suba lakeside villages. Other grains, sorghum and millet, are predominantly home consumed, while over $80 \%$ of beans on average are likewise retained for home consumption. Amongst livestock products, the mean subsistence share of milk is $75 \%$, and for chickens, $66 \%$. Goats, on the other hand, are kept mainly for cash sales, so that their home consumption proportion is under $20 \%$ of total production.

\section{Table 7: Selected outputs, share consumed by households, by study area (\%)}

\begin{tabular}{lcccc}
\hline $\begin{array}{l}\text { Agricultural } \\
\text { activities }\end{array}$ & $\begin{array}{c}\text { Suba Inland } \\
\mathbf{n = 7 0}\end{array}$ & $\begin{array}{c}\text { Suba Lake } \\
\mathbf{n = 1 0 5}\end{array}$ & $\begin{array}{c}\text { Bomet } \\
\mathbf{n = 1 7 5}\end{array}$ & $\begin{array}{c}\text { Total } \\
\mathbf{n = 3 5 0}\end{array}$ \\
\hline Crops & & & & \\
Maize & 88.2 & 99.3 & 86.6 & 90.0 \\
Sorghum & 77.3 & 99.8 & 91.1 & 89.1 \\
Millet & 77.1 & 99.7 & 100.0 & 95.1 \\
Beans & 71.7 & 68.8 & 86.3 & 81.8 \\
Livestock & & & & \\
Milk & 93.0 & 86.5 & 67.5 & 75.3 \\
Chickens & 76.4 & 89.9 & 29.6 & 65.6 \\
Goats & 25.5 & 22.9 & 10.5 & 17.5 \\
\hline
\end{tabular}

Source: Ibid.

The role of subsistence agriculture in rural livelihoods in these study locations is further refined by reference to the overall share of own consumption by value in household income across different income levels. ${ }^{20}$ The relevant data are shown in Table 8. In general, reliance on subsistence falls steeply from $47 \%$ for the bottom income quartile to $9 \%$ for the top quartile. The pattern of this decline varies between study locations. In Suba fishing villages, the major drop occurs between the lowest and the second-lowest income quartiles. This reflects the rising importance of net income from fishing as income rises in these villages, at the same time revealing that artisanal fishing families are not, in fact, the 'poorest of the rural poor'. In Bomet, by contrast, there is a steady fall in reliance on subsistence across the income ranges from $49 \%$ for the lowest quartile to $16 \%$ for the top quartile.

20. For this purpose, subsistence consumption of crops and livestock products is valued at the average farmgate prices cited in the completed household survey forms. 


\section{Table 8: Share of subsistence consumption in total income by income quartiles, by study area (\%)}

\begin{tabular}{lccccc}
\hline Sample & \multicolumn{4}{c}{ Income quartile } & \multicolumn{2}{c}{ Total $(\mathbf{n}=350)$} \\
& I & II & III & IV & \\
\hline Suba Inland & 48.2 & 33.5 & 20.2 & 7.6 & 15.5 \\
Suba Lake & 45.3 & 17.7 & 11.2 & 4.7 & 8.7 \\
Bomet & 48.7 & 39.3 & 20.6 & 16.5 & 22.1 \\
All villages & 47.0 & 31.3 & 19.2 & 8.8 & 15.1 \\
\hline
\end{tabular}

Source: Ibid.

It can be inferred from these findings that the rural poor tend to be trapped in a subsistence agriculture mode of existence that allows little scope to move out of poverty because lack of cash drastically reduces the range of options open to family members. ${ }^{21}$ Households in the lowest income quartile are the most vulnerable to unexpected adverse events, whether of a personal nature (accident or illness) or due to larger-scale causes (drought or floods), due in part to their excessive reliance on non-monetised production. A vicious circle operates here, since it is partly the riskiness of engaging in market transactions that reinforces subsistence behaviour, and that in turn closes down options that would make livelihoods more robust in the face of shocks.

The composition of household total incomes provides relevant insights into the way asset differences result in different patterns of income earning across income levels. Overall, in the sample villages, 32\% of household incomes arose from agricultural (crop and livestock) activities, while 68\% was attributable to non-farm sources (Table 9). If fishing is included as agriculture, these proportions become 46 and $54 \%$ respectively, and these are reasonably close to a 50:50 pattern that tends to characterise, in a broad way, contemporary rural livelihoods in the region (Ellis and Freeman, 2004). Within these aggregate categories important subsidiary patterns are revealed by income level. Crop and livestock income falls steeply as a proportion of total household income across the income quartiles, from 65 to $22 \%$. Transfer income (mainly remittances) also falls in an uneven way as income rises. On the other hand, non-farm business income (self-employment) rises steeply from $10 \%$ to nearly $40 \%$ of total income; and fishing income, even though originating in only three villages within this overview picture, rises from $4 \%$ to $18 \%$ of income. ${ }^{22}$ Figure 4 illustrates how these mean income portfolios change between the lowest and highest income quartiles.

21. This does not imply a subsistence economy. The poor are intimately linked to markets mainly through food purchases, wage and migrant labour, and petty trade.

22. In the three fishing villages themselves, fishing income remains more or less the same proportion of incomes across the income ranges; however, factors to do with varying absolute levels of total income in different places and sub-categories cause this result to occur in the aggregate picture. 
Table 9: Income portfolios by income quartile, whole sample, composition of household incomes (\%)

\begin{tabular}{|c|c|c|c|c|c|}
\hline \multirow[t]{2}{*}{ Income sources } & \multicolumn{4}{|c|}{ Income quartile } & \multirow[b]{2}{*}{$\begin{array}{l}\text { Total } \\
\mathbf{n}=70\end{array}$} \\
\hline & $\underset{n=17}{I}$ & $\underset{n=18}{\text { II }}$ & $\underset{n=18}{\text { III }}$ & $\underset{\mathbf{n}=17}{\mathrm{IV}}$ & \\
\hline Maize & 21.4 & 6.8 & 4.9 & 1.6 & 3.7 \\
\hline Sorghum & 4.3 & 1.8 & 1.0 & 0.9 & 1.2 \\
\hline Other crops & 6.5 & 6.9 & 9.1 & 6.1 & 6.8 \\
\hline Milk & 20.2 & 24.0 & 21.1 & 9.3 & 14.0 \\
\hline Livestock & 12.4 & 14.6 & 9.4 & 3.6 & 6.5 \\
\hline Sub-total Agriculture & 64.8 & 54.1 & 45.5 & 21.5 & 32.2 \\
\hline Wages & 10.5 & 7.1 & 21.6 & 19.9 & 18.3 \\
\hline Self-employment & 9.5 & 23.5 & 16.7 & 38.5 & 31.0 \\
\hline Transfers & 11.5 & 6.9 & 7.3 & 2.4 & 4.3 \\
\hline Fish & 3.8 & 8.5 & 8.9 & 17.7 & 14.2 \\
\hline Total & 100.0 & 100.0 & 100.0 & 100.0 & 100.0 \\
\hline
\end{tabular}

Source: Ibid.

Figure 4: Income portfolio comparisons, whole sample
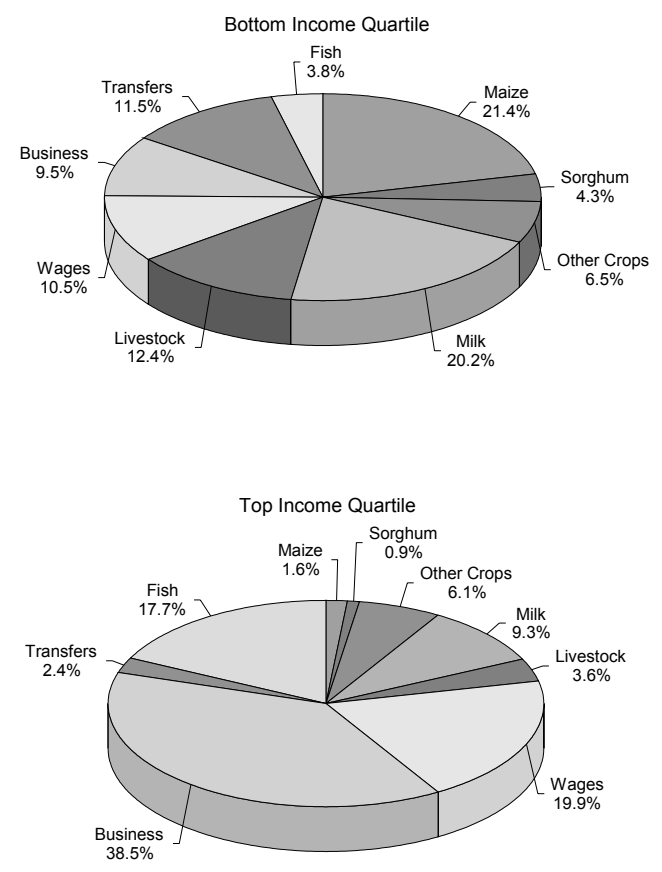
Becoming less reliant on crop and livestock production is part of the process of climbing out of poverty, in Kenya as well as elsewhere, but this is not the end of the story. A further notable feature is that land productivity tends to rise with increasing income. Table 10 reveals a slightly mixed picture across different locations, although the overall effect is unambiguous. In Bomet, net farm output per hectare for the top income quartile is over five times that for the bottom income quartile. In Suba, the quartile figures do not show such a smooth or steep increase, but nevertheless the net farm output per hectare of the top quartile is nearly double that of the bottom quartile. It must be borne in mind that the picture is complicated for Suba lakeside villages by the exclusion of fish from this indicator. Overall, across all 350 households, net farm output per hectare is three times higher for the top quartile than the bottom quartile.

\section{Table 10: Agricultural output value per ha (KShs/ha)}

\begin{tabular}{|c|c|c|c|c|c|}
\hline \multirow{2}{*}{ Study areas } & \multicolumn{4}{|c|}{ Income quartile } & \multirow{2}{*}{$\begin{array}{c}\text { Total } \\
(n=350)\end{array}$} \\
\hline & $\mathbf{I}$ & II & III & IV & \\
\hline Suba Inland & 6,692 & 11,552 & 10,961 & 10,621 & 10,220 \\
\hline Suba Lake & 5,933 & 9,283 & 8,288 & 11,868 & 8,858 \\
\hline Bomet & 18,120 & 43,576 & 69,363 & 104,325 & 65,122 \\
\hline All villages & 10,668 & 21,087 & 28,414 & 34,153 & 25,316 \\
\hline
\end{tabular}

Source: Ibid.

This finding reinforces the cumulative nature of becoming better-off in rural Kenya, a process that has been observed by researchers in other parts of the country (for example, Evans and Ngau, 1991). Non-farm income enables the household to hire labour in order to undertake timely cultivation practices, and helps to fund the purchase of farm cash inputs; conversely, hiring out labour by poor households causes their own farm productivity to stagnate or fall. Livestock ownership plays a reinforcing role in virtuous spirals of accumulation, just as its absence contributes to the inability of poorer households to climb onto the first rung of the 'ladder' leading out of poverty.

\section{Institutions and rural poverty reduction}

The term 'institutions' is used here to describe customs, rules, regulations, laws, public agencies, and the way these habitually, and from precedence, go about doing what they do. The qualitative research conducted at micro level in villages approached the understanding of institutions from several different perspectives, including asking people in group discussions to distinguish agencies that had real impacts on their lives, from those that did not; identifying the strengths and weaknesses of institutions; ranking institutions according to how helpful or unhelpful they were in regard to gaining a living; and listing official and unofficial taxes, levies and licences that individuals were subjected to as they went about making a living. The key insights gained from this exercise across ten villages, are summarised as follows:

(i) Rural Kenyans characterise government agencies and office holders of all kinds as the least helpful institutions. These include local government administration 
(County Councils), district commissioners, officials of the agricultural, forestry and fisheries departments, councillors, MPs, and sometimes even chiefs and village elders (although opinions on the latter two groups were more mixed). Villagers have clear notions of public service and about their rights as citizens, and they express indignation at perceived delivery failures and at the frequency with which bribes must be paid in order to secure services that should legally be free. In this respect, the research confirmed findings about corruption and governance that were widely aired in the consultations that preceded the preparation of the 2001 PRSP.

(ii) Rural Kenyans are subject to many different types of taxes, both legal ones that are administered by district-level revenue authorities or the local offices of government departments, and illegal ones that are levied under various guises by individuals or groups holding positions that enable them to exercise that sort of leverage. Table 11 gives a provisional sense of this taxation regime, compiled from information volunteered in village discussions and by key informants. This compilation does not represent a complete summary of taxes or tax rate variations mentioned by villagers, nor does it capture the impotence felt by ordinary rural citizens over the arbitrary and capricious working of the tax system in practice. The tax question is an important one for rural poverty reduction in Kenya and is considered in a little more detail below.

(iii) Community groups are popular institutions in Kenya villages. Women's groups were mentioned favourably in the majority of case-study villages, with occasional sniping by men about the amount of women's time they took up. Several types of rotating savings groups were mentioned, based on regular contributions or 'membership fees' by participants, and rotating access to the funds thus created. These included burial groups in several villages. Also prevalent in the case-study villages were youth groups, although these provoked more varied reactions in group discussions, from enthusiasm to disapproval.

(iv) Villages generally seem to have beneficial experiences with the direct assistance they receive from donors and NGOs; indeed major differences have often been made to people's lives by the provision of piped water, wells, agricultural extension advice, input supplies, food-for-work schemes, credit provision, and formation of village groups with specified objectives, by organisations such as CARE Kenya, World Vision, Finaid and IFAD. In general, in group discussions these were amongst the more highly rated institutions, unless they had raised expectations that had not subsequently been fulfilled.

(v) Churches play an important role in Kenya villages, and were often listed in village discussion groups as the most important or most helpful institutions. Most villages had more than one denomination of church to which different families belonged, and some had mission stations that carried out a wide variety of development activities. Churches or missions also often provided services that the public sector failed to provide satisfactorily, for example in relation to schools, preventive medicine and health clinics. In addition, such institutions sometimes provided direct support to the poor, by organising alms, or in other ways mobilising resources to assist those in desperate need. 
Amongst the foregoing, taxation requires special mention, not just because it was universally regarded as one of the most important barriers to achieving a satisfactory living, but also because of its haphazard and cumulative incidence, its close association with poor governance, and the absence of any identifiable links between taxes levied and services delivered in return. These links are a cornerstone of the relationship between government and governed in working democratic societies (Moore, 1998). Rural Kenyans were entirely aware of the absence of these links in relation to their own taxation, and in some villages articulated this with admirable clarity.

Economists have recognised certain basic principles of good taxation practice, going back to Adam Smith's The Wealth of Nations, first published in 1776. These principles or 'canons' include non-distortion of relative prices; simplicity so that both citizens and tax collectors have a clear understanding of the tax instrument and the level being applied; low cost of collection relative to the amount of tax collected; and fairness in the incidence of the tax on different social groups, because perceptions about 'fairness' are an important ingredient of the acceptability of the taxation to the population, and their resulting preparedness to pay rather than dodge taxes. It is doubtful that the typical tax regime found in rural Kenya, as illustrated in Table 11, complies with many of these precepts. ${ }^{23}$ Flat-rate commodity taxes, such as those on food crops and livestock, are variable in level and distort relative prices; the tax regime is complex and represents itself as a dense thicket of distinct payments; the cost of collection is likely to be high relative to the amount of tax that actually finds its way into government or local council coffers; and many of the taxes listed in Table 11 are regressive in nature, hitting the incomes of the rural poor more than the incomes of the better-off or the rich. Added to this, the rich and well-connected tend to be able to avoid taxes that other citizens have to pay, all the more so when these are illegal or unofficial taxes that they are better able to resist paying.

Taxation constitutes one component of what appears from qualitative research findings as a fundamentally disabling public sector institutional environment in rural Kenya. This is shown by the low ranking, disparagement, and distrust with which public officialdom of all kinds is held by people in villages. These are factors that are seldom given much attention in strategic documents related to poverty reduction, even though they are often mentioned in participatory poverty assessments and related similar consultative exercises. In the Kenya case where democratic decentralisation is still in its planning stages, it is pertinent to recognise that such factors do not just disappear with the advent of decentralised local government; indeed, without due attention some of them can even inadvertently be made worse.

23. Kenya is not by any means unique in this respect; see, for example, Fjeldstad (2001), as well as the Uganda and Tanzania examples given in Ellis and Bahiigwa (2003) and Ellis and Mdoe (2003). 


\section{Table 11: Examples of formal and informal taxes and levies in rural Kenya}

\begin{tabular}{|c|c|c|}
\hline Category of tax & $\begin{array}{l}\text { Amount to pay } \\
\text { (Kshs) }\end{array}$ & Comment or description \\
\hline $\begin{array}{l}\text { - clothes trading } \\
\text { - land transactions } \\
\text { - jua kali set-up fee }\end{array}$ & $\begin{array}{r}70 \text { per week } \\
400 \text { per week } \\
800 \text { per week } \\
100 \text { per bale } \\
1,200 \\
1,000 \\
2,100\end{array}$ & $\begin{array}{l}\text { Paid to County Council } \\
\text { - Suba district } \\
\text { - Bomet district } \\
\text { - non-refundable application fee } \\
\text { - survey fee } \\
\text { - licence fee charged to start-ups }\end{array}$ \\
\hline $\begin{array}{l}\text { Crops taxes } \\
\text { - maize or beans per debe }\end{array}$ & 20 & $\begin{array}{l}\text { Paid to County Council } \\
\text { - normally paid on entry to the market with the } \\
\text { commodity to be sold }\end{array}$ \\
\hline $\begin{array}{l}\text { - maize or millet per sack } \\
\text { - vegetables per sack } \\
\text { - cassava per sack } \\
\text { - market levies on crops }\end{array}$ & $\begin{aligned} 60-90 & \\
80 & \text { fresh) } \\
80 & \text { (fresh) } \\
20 & \text { per day }\end{aligned}$ & - receipts, say $10 /-$, but payment is usually $20 /-$ \\
\hline $\begin{array}{l}\text { Livestock taxes } \\
\text { - licence to trade } \\
\text { - market charges per cow } \\
\text { - movement permit cow } \\
\text { - market levy per goat } \\
\text { - sales tax per cow } \\
\text { - sales tax per goat } \\
\text { - sales tax per hen }\end{array}$ & $\begin{array}{r}20,000 \\
50 \\
50 \\
30 \\
10-100 \\
10-35 \\
20\end{array}$ & $\begin{array}{l}\text { Paid to County Council } \\
\text { - paid from Suba to Central Nyanza } \\
\text { - collected and retained by livestock officer } \\
\text { - normally paid on entry to the market with the } \\
\text { commodity to be sold }\end{array}$ \\
\hline $\begin{array}{l}\text { Fish taxes (Suba District) } \\
\text { Formal } \\
\text { - fishing boat licence } \\
\text { - private mark for boats } \\
\text { - certificate of registration } \\
\text { - fisheries marketing licence } \\
\text { - market tax per day } \\
\text { - fish selling cess per sack } \\
\text { - Confiscation fee }\end{array}$ & $\begin{array}{r}1000 \\
300 \\
100 \\
350 \\
20 \\
40 \\
2,800\end{array}$ & $\begin{array}{l}\text { - marketing licence and health certificate } \\
\text { - daily charge for small-scale selling } \\
\text { - dried omena } \\
\text { - to release boats confiscated on the grounds of } \\
\text { not being lakeworthy }\end{array}$ \\
\hline $\begin{array}{l}\text { Informal } \\
\text { - Fuel for fisheries officers } \\
\text { - bribes to get health certificates }\end{array}$ & $\begin{array}{l}200 \\
400\end{array}$ & $\begin{array}{l}\text { - unofficial payment to officers } \\
\text { - Health Department officials }\end{array}$ \\
\hline $\begin{array}{l}\text { Informal dues } \\
\text { - public holiday contributions } \\
\text { cash (to chiefs) } \\
\text { - also paid in kind } \\
\text { - 'entertainment' of DOs or } \\
\text { DCs } \\
\text { - procurement of ID forms and } \\
\text { vetting }\end{array}$ & $\begin{array}{r}150 \text { per hh } \\
30-50 \text { person } \\
\text { goats or hens } \\
280 \text { per hh } \\
300 \text { (bribe) }\end{array}$ & $\begin{array}{l}\text { Paid to chiefs and government officials } \\
\text { - payable to chiefs or government officers } \\
\text { - wide variety of payment types of methods } \\
\text { recorded } \\
\text { - lack of compliance can involve forceful } \\
\text { confiscation of household items or livestock } \\
\text { that are later sold through auction }\end{array}$ \\
\hline
\end{tabular}

Source: Village reports for 5 villages in Suba district and 5 villages in Bomet district. 


\section{Synthesis and policy inferences}

This article set out to make the links between a micro-level understanding of the circumstances and prospects of the rural poor in two districts in rural Kenya, and macrolevel strategic approaches to poverty reduction including the PRSP and the Strategy for Economic Recovery, as well as stated government intentions to put into effect democratic decentralisation at some point in the future. At the micro level, the sustainable livelihoods framework is utilised to gain a more accurate picture of the asset and activity patterns that characterise the poor in particular, and the institutional context that either blocks or enables rural citizens in their pursuit of more secure livelihoods over time. At the macro level, the question is posed whether strategic policy documents formulate the poverty reduction problem in a way that addresses the real barriers that rural citizens confront in their efforts to construct pathways out of poverty.

The picture that emerges from the micro-level research is that poorer groups in rural Kenya depend principally on food-crop agriculture and seasonal wage income for their livelihoods, while the better-off combine food-crop agriculture with rising livestock holdings and widespread engagement in non-farm self-employment activities. A rural development strategy paper finalised in Kenya shortly prior to the 2003 change of government laid considerable emphasis on raising productivity in agriculture as the primary rural development goal (Government of Kenya, 2002). The evidence summarised in this article suggests that rural poverty reduction requires a broader starting point than this, and is as much to do with encouraging and facilitating diversity and mobility as promoting one sector in particular.

This is not to underestimate the significance of food-crop agriculture in contributing to the food security of the rural poor, nor to dismiss gains that could be made by raising crop yields. Nevertheless, Kenya's own past demonstrates that levels of rural poverty are closely related to the presence or absence of migration and urban employment opportunities. There is no magic policy solution to rising rural poverty, but it is as likely to be reversed by stimulating investment and employment in small and large towns as by focusing on farm output improvements on their own. Moreover, creating institutional contexts that are broadly encouraging to risk-taking, investment and enterprise across sectors would provide more propitious circumstances for people to generate their own pathways out of poverty. Individual agency is often underestimated in policy discourses that focus almost exclusively on things that governments 'ought to do', rather than on things that the government should 'not be doing', i.e. placing blockages in the way of people's own agency.

The micro-level research certainly reveals a local-level public sector institutional environment that tends to be hampering rather than facilitating people's own endeavours to construct pathways out of poverty. The most concrete manifestation of this is the dense thicket of fees, dues, levies, taxes, permits and licences that confront rural Kenyans whenever they engage in market transactions beyond the village, or begin to create non-farm businesses. It is apparent that official taxes have grown in a haphazard way, with no consideration of their distorting effects on prices, and little regard to their cumulative impact. Beyond this, informal taxes are even more accidental in their incidence, and serve to raise rather than lower the array of risks that people have to deal with, thus making livelihoods more rather than less vulnerable. Finally, the tax relationship between government and governed tends to set the tone for broader 
interactions, and leads to more generalised behaviours in which rural populations are treated as subjects rather than citizens (Fjeldstad, 2001).

In the light of the micro evidence, therefore, the creation of a facilitating environment that encourages rather than blocks the flourishing of diverse monetised rural and urban activities in Kenya needs to be prioritised in rural thinking on poverty reduction. This means considering carefully the relationship between future intended modalities of decentralisation, including fiscal decentralisation, and the poverty reduction process, whatever form that eventually takes.

Kenya is uniquely placed to learn from divergences between the intentions and effective outcomes of decentralisation as they have been occurring in neighbouring countries. It is also in a position to build into its future strategic policy processes a commitment to identify, evaluate, and seek to diminish those factors in the institutional and fiscal environment that are hostile and discouraging to trade, investment, risk-taking and enterprise in rural areas. Critically, the point must be emphasised that building schools and improving roads in rural areas will not by themselves result in rapid poverty reduction if the public sector institutional environment remains deeply discouraging to dynamic and diversifying rural livelihoods.

first submitted June 2003 final revision accepted December 2003

\section{References}

Allison, E. and Mvula, P. (2002) Fishing Livelihoods and Fisheries Management in Malawi. LADDER Working Paper No.22. Norwich: Overseas Development Group, University of East Anglia, September.

Bebbington, A. (1999) 'Capitals and Capabilities: A Framework for Analyzing Peasant Viability, Rural Livelihoods and Poverty', World Development 27 (12): 2021-44.

Booth, D., Holland, J., Hentschel, J., Lanjouw, P. and Herbert, A. (1998) Participation and Combined Methods in African Poverty Assessment: Renewing the Agenda. London: Social Development Division, UK Department for International Development, February.

Bryceson, D. F. (1996) 'Deagrarianization and Rural Employment in Sub-Saharan Africa: A Sectoral Perspective', World Development 24 (1): 97-111.

Bryceson, D. F. and Jamal, V. (eds) (1997) Farewell to Farms: Deagrarianisation and Employment in Africa. Research Series No.1997/10. Leiden: African Studies Centre.

Carney, D. (1998) 'Implementing the Sustainable Rural Livelihoods Approach', in D. Carney (ed.), Sustainable Rural Livelihoods: What Contribution Can We Make? London: Department for International Development.

Carney, D., Drinkwater, M., Rusinow, T., Neefjes, K., Wanmali, S. and Singh, N. (1999) Livelihoods Approaches Compared. London: Department for International Development.

Daniels, L. (1999) 'The Role of Small Enterprises in the Household and National Economy in Kenya: A Significant Contribution or a Last Resort', World Development 27 (1): 55-65. 
Daniels, L. and Mead, D. C. (1998) 'The Contribution of Small Enterprises to Household and National Income in Kenya', Economic Development and Cultural Change 47 (1): 45-71.

Ellis, F. (1998) 'Survey Article: Household Strategies and Rural Livelihood Diversification', The Journal of Development Studies 35 (1): 1-38.

Ellis, F. (2000) Rural Livelihoods and Diversity in Developing Countries. Oxford: Oxford University Press.

Ellis, F. and Bahiigwa, G. (2003) 'Livelihoods and Poverty Reduction in Uganda', World Development 31 (6): 997-1013.

Ellis, F. and Mdoe, N. (2003) 'Livelihoods and Rural Poverty Reduction in Tanzania', World Development 31 (8): 1367-84.

Ellis, F., Kutengule, M. and Nyasulu, A. (2003) 'Livelihoods and Rural Poverty Reduction in Malawi', World Development 31 (9): 1495-1510.

Ellis, F. and Freeman, H. A. (2004) 'Rural Livelihoods and Poverty Reduction Strategies in Four African Countries', Journal of Development Studies 40 (4), April.

Evans, H. E. and Ngau, P. (1991) 'Rural-Urban Relations, Household Income Diversification and Agricultural Productivity', Development and Change 22: 51945.

Fjeldstad, O.-H. (2001) 'Donors Turn Blind Eye to Extortion in Tax Collection in Africa', Development Today XI (8), May.

Francis, E. (1998) 'Gender and Rural Livelihoods in Kenya', Journal of Development Studies 35 (2): 72-95.

Francis, E. (2000) Making a Living: Changing Livelihoods in Rural Africa. London: Routledge.

Francis, E. and Hoddinott, J. (1993) 'Migration and Differentiation in Western Kenya: A Tale of Two Sub-Locations', Journal of Development Studies 30 (1): 115-45.

Government of Kenya (2001) Poverty Reduction Strategy Paper for the Period 20012003. Nairobi: Ministry of Finance and Planning, June.

Government of Kenya (2002) Kenya Rural Development Strategy 2002-2017. Final Draft. Nairobi: Government of Kenya, March.

Government of Kenya (2003) Strategy for Economic Recovery: A Discussion Paper prepared for the Ministry of Planning. Nairobi: Ministry of Planning, March.

Grandin, B. E. (1988) Wealth Ranking in Smallholder Communities: A Field Manual. London: Intermediate Technology Publications.

Heyer, J., Maitha, J. K. and Senga, W. M. (eds) (1976) Agricultural Development in Kenya: An Economic Assessment. Oxford: Oxford University Press.

Hoddinott, J. (1994) 'A Model of Migration and Remittances Applied to Western Kenya', Oxford Economic Papers 46: 459-76.

International Labour Office (ILO) (1972) Employment Incomes and Equality: A Strategy for Increasing Productive Employment in Kenya. Geneva: ILO.

Jabara, C. L. (1985) 'Agricultural Pricing Policy in Kenya', World Development 13 (5): 611-26.

Johnston, B. F. (1989) 'The Political Economy of Agricultural Development in Kenya and Tanzania', Food Research Institute Studies XXI (3): 205-64.

Kanbur, R. (ed.) (2001) Qualitative and Quantitative Poverty Appraisal: Complementarities, Tensions and the Way Forward. Working Paper No. 2001-05. 
Ithaca, NY: Department of Applied Economics and Management, Cornell University, May.

Killick, T. (ed.) (1981) Papers on the Kenyan Economy: Performance, Problems and Policies. Nairobi: Heinemann.

King, K. (1996) Jua Kali Kenya: Change and Development in an Informal Economy 1970-95. London: James Currey.

Kitching, G. (1980) Class and Economic Change in Kenya: The Making of an African Petite-Bourgeoisie. New Haven, CT: Yale University Press.

Lamb, G. and Muller, L. (1982) Control, Accountability, and Incentives in a Successful Development Institution: The Kenya Tea Development Authority. Staff Working Paper No. 550. Washington, DC: World Bank.

Leys, C. (1975) Underdevelopment in Kenya: The Political Economy of NeoColonialism 1964-1971. London: Heinemann.

Livingstone, I. (1991) 'A Reassessment of Kenya's Rural and Urban Informal Sectors', World Development 19 (6): 651-70.

Lofchie, M. F. (1989) The Policy Factor: Agricultural Performance in Kenya and Tanzania. Boulder, CO: Lynne Rienner.

Moore, M. (1998) 'Death without Taxes: Democracy, State Capacity, and Aid Dependency in the Fourth World', in G. White and M. Robinson (eds), Towards a Democratic Developmental State. Oxford: Oxford University Press.

Moser, C. O. N. (1998) 'The Asset Vulnerability Framework: Reassessing Urban Poverty Reduction Strategies', World Development 26 (1): 1-19.

Murton, J. (1999) 'Population Growth and Poverty in Machakos District, Kenya', The Geographical Journal 165 (1): 37-46.

National Rainbow Coalition (NARC) (2002) NARC Manifesto. Nairobi: NARC Press Office, December.

Pauly, D. (1997) 'Small-Scale Fisheries in the Tropics: Marginality, Marginalisation, and Some Implications for Fisheries Management', in E. K. Pikitch, D. D. Huppert and M. P. Sissenwine (eds), Global Trends: Fisheries Management. Bethesda, MD: American Fisheries Society.

Saith, A. (1992) The Rural Non-Farm Economy: Processes and Policies. Geneva: World Employment Programme, ILO.

Scoones, I. (1998) Sustainable Rural Livelihoods: A Framework for Analysis. IDS Working Paper No. 72. Brighton: Institute of Development Studies at the University of Sussex.

Sen, A. K. (1981) Poverty and Famines: An Essay on Entitlements and Deprivation. Oxford: Clarendon Press.

Tiffen, M., Mortimore, M. and Gichuki, F. (1994) More People, Less Erosion: Environmental Recovery in Kenya. Chichester: John Wiley.

White, H. (2002) 'Combining Quantitative and Qualitative Approaches in Poverty Analysis', World Development 30 (3): 511-22.

World Bank (2000) Kenya Country Assistance Evaluation. Report No. 21409. Washington, DC: World Bank, November.

World Bank (2002) World Development Report 2002: Building Institutions for Markets. New York: Oxford University Press for the World Bank. 